\title{
Komentarz do art. 24-25 ustawy \\ z dnia 9 czerwca 2011 r. - Prawo geologiczne i górnicze Dz.U. 2020, poz. 1064 ze zm.
}

Art. 24.

1. We wniosku o udzielenie koncesji, poza wymaganiami przewidzianymi przepisami z zakresu ochrony środowiska, określa się:

1) właścicieli (użytkowników wieczystych) nieruchomości, w granicach których ma być wykonywana zamierzona działalność, oraz oznaczenie tych nieruchomości zgodnie z ewidencją gruntów i budynków; wymóg ten nie dotyczy poszukiwania i rozpoznawania złóż węglowodorów;

2) prawa wnioskodawcy do nieruchomości (przestrzeni), w granicach której ma być wykonywana zamierzona działalność, lub prawo, o ustanowienie którego ubiega się wnioskodawca;

3) czas, na jaki koncesja ma być udzielona, wraz ze wskazaniem terminu rozpoczęcia dzialalności;

4) środki, jakimi wnioskodawca dysponuje w celu zapewnienia prawidłowego wykonywania zamierzonej działalności;

5) wykaz obszarów objętych formami ochrony przyrody; wymóg ten nie dotyczy przedsięwzięć, dla których jest wymagana decyzja o środowiskowych uwarunkowaniach;

6) sposób przeciwdziałania ujemnym wpływom zamierzonej działalności na środowisko;

7) firmę przedsiębiorcy, oznaczenie jego siedziby i adresu albo miejsca zamieszkania i adresu oraz adresu głównego miejsca wykonywania działalności gospodarczej; 
8) numer w rejestrze przedsiębiorców w Krajowym Rejestrze Sądowym, o ile przedsiębiorca taki numer posiada, oraz numer identyfikacji podatkowej (NIP);

9) rodzaj i zakres wykonywania zamierzonej działalności.

2. Do wniosku o udzielenie koncesji dołącza się dowody istnienia określonych w nim okoliczności, a w przypadku potwierdzenia danych, o których mowa w ust. 1 pkt 1 - wypis z ewidencji gruntów i budynków.

3. Załączniki graficzne sporządza się zgodnie z wymaganiami dotyczącymi map górniczych, z zaznaczeniem granic podziału terytorialnego kraju.

4. W uzasadnionych przypadkach organ koncesyjny może żądać złożenia kopii wniosku o udzielenie koncesji wraz z zalącznikami.

5. Jeżeli dla przestrzeni objętej wnioskiem została już sporządzona dokumentacja geologiczna, organ koncesyjny może żądać jej przedłożenia.

Prawo przedsiębiorców ${ }^{1}$ nakłada na organy administracji (w zakresie ich właściwości) obowiązek udzielania przedsiębiorcy informacji o warunkach podejmowania, wykonywania i zakończenia działalności gospodarczej (art. 15). W Biuletynie Informacji Publicznej, na stronie podmiotowej urzędu obsługującego organ koncesyjny, należy zamieścić szczegółowe informacje o wszelkich warunkach uzyskania koncesji (tzw. obowiązek informacji, art. 38). Obejmują one nie tylko określenie wymagań, jakim muszą odpowiadać wnioski koncesyjne, ale również wskazanie przesłanek, którymi kieruje się organ koncesyjny, orzekając w omawianych sprawach. W istocie rozwiązanie to można traktować jako szczególną postać obowiązku udostępnienia informacji publicznych oraz tzw. zasady informowania wypowiedzianej w art. 9 k.p.a ${ }^{2}$. Ten ostatni przepis przewiduje, że „organy administracji publicznej są obowiązane do należytego i wyczerpującego informowania stron o okolicznościach faktycznych i prawnych, które mogą mieć wpływ na ustalenie ich praw i obowiązków będących przedmiotem postępowania administracyjnego. Organy czuwają nad tym, aby strony i inne osoby uczestniczące $\mathrm{w}$ postępowaniu nie poniosły szkody z powodu nieznajomości prawa, i w tym celu udzielają im niezbędnych wyjaśnień i wskazówek". Przedstawienie relacji wspomnianych rozwiązań wykracza poza ramy niniejszego komentarza. Dość wspomnieć, że art. 15 p.p. dotyczy informacji udostępnianej poza toczącym się postępowaniem (koncesyjnym), art. 9 k.p.a. dotyczy już toczących się postępowań administracyjnych. Obowiązki te nierzadko są jednak ignorowane przez praktykę. Bezspornie natomiast żaden z tych przepisów nie może być traktowany jako nakaz udzielania stronom pomocy prawnej, zwłaszcza że oczekiwania stron postępowań koncesyjnych nierzadko mogą być diametralnie rozbieżne.

\footnotetext{
${ }^{1}$ Ustawa z dnia 6 marca 2018 r. — Prawo przedsiębiorców (Dz.U. 2021, poz. 162, dalej: p.p.).

${ }^{2}$ Ustawa z dnia 14 czerwca 1960 r. - Kodeks postępowania administracyjnego (t.j. Dz.U. 2021, poz. 735 , dalej: k.p.a.).
} 
Postępowanie koncesyjne (czyli w sprawie udzielenia koncesji) może zostać wszczęte wyłącznie w trybie wnioskowym. Nie ma możliwości wszczęcia go z urzędu. Komentowany art. 24 formułuje tzw. ogólne wymagania wniosku koncesyjnego. Są one wyznaczane przez:

- ustawę dnia 3 października 2008 r. o udostępnianiu informacji o środowisku i jego ochronie, udziale społeczeństwa w ochronie środowiska oraz o ocenach oddziaływania na środowisko ${ }^{3}$,

- Prawo geologiczne i górnicze.

Rozwiązanie to nie jest jednak wyczerpujące, bowiem w pewnym zakresie wymagania wniosku koncesyjnego kształtowane są też przez przepisy k.p.a. (art. 63). W obecnym stanie prawnym wymagania wniosku koncesyjnego nie są określane przez Prawo przedsiębiorców.

Konsekwencją zasady praworządności wyrażonej w art. 7 Konstytucji (a także art. 6 k.p.a.) jest to, że organ koncesyjny nie może żądać ani uzależniać swojej decyzji w sprawie podjęcia, wykonywania i zakończenia działalności gospodarczej od spełnienia przez wnioskodawcę dodatkowych (w stosunku do określonych prawem) wymagań, w szczególności od przedłożenia dokumentów lub ujawnienia danych, nieprzewidzianych przepisami prawa. Nie wolno mu również żądać ani uzależnić swoich rozstrzygnięć od przedłożenia dokumentów w formie oryginału, poświadczonej kopii lub poświadczonego tłumaczenia, chyba że obowiązek taki jest przewidziany prawem (art. 28 p.p.). Wyważenie szczegółów może niekiedy być dość trudne, przede wszystkim ze względu na uznaniowy charakter niektórych przesłanek koncesjonowania.

Odesłanie do wymagań przewidzianymi przepisami z zakresu ochrony środowiska oznacza, że jeżeli zamierzona koncesja dotyczy przedsięwzięcia zaliczonego do kategorii mogących (zawsze bądź potencjalnie) znacząco oddziaływać na środowisko, elementem wniosku koncesyjnego musi być decyzja w sprawie środowiskowych uwarunkowań (art. 72 ust. 1 pkt 4 u.o.o.ś. W zw. z rozporządzeniem Rady Ministrów z dnia 10 września 2019 r. w sprawie przedsięwzięć mogących znacząco oddziaływać na środowisko ${ }^{4}$ ). Co więcej, decyzja ta $\mathrm{w}$ zasadzie musi być ostateczna, chyba że decyzji nieostatecznej nadano rygor natychmiastowej wykonalności ${ }^{5}$.

Ad. 1. Określenie właścicieli (użytkowników wieczystych) nieruchomości, w granicach których ma być wykonywana zamierzona działalność, polega na wskazaniu ich danych identyfikujących (nazwisko i imię bądź nazwa danego podmiotu, adres zamieszkania bądź siedziby). Oznaczenie nieruchomości zgodnie $\mathrm{z}$ ewidencją gruntów i budynków polega na wskazaniu numeru działki oraz jej lokalizacji. Nie jest natomiast dostatecznie jasne, czy wszystkie te wymaga-

3 Dz.U. 2021, poz. 247, dalej: u.o.o.ś.

4 Dz.U. 2019, poz. 1839.

5 Zob. m.in. wyroki NSA: z dnia 8 grudnia 2011 r., sygn. akt II OSK 2169/11 oraz z dnia 18 maja 2016 r., sygn. akt II OSK 1066/15. 
nia ulegają wyłączeniu w odniesieniu do poszukiwania (rozpoznawania) złóż węglowodorów, czy też dotyczy to tylko geodezyjnego oznaczenia nieruchomości. Wypada opowiedzieć się za pierwszym z tych rozwiązań. Funkcją omawianego przepisu jest natomiast ustalenie stron postępowania koncesyjnego. Nie sposób jednak zakładać, że właściciele (użytkownicy wieczyści) nieruchomości, w granicach których ma być wykonywana zamierzona działalność polegająca na poszukiwaniu (rozpoznawaniu) węglowodorów (np. odwierty lub inne badania), nie są stronami postępowania koncesyjnego (zob. art. 41 pr.g.g.).

W praktyce realizacja obowiązku określonego w pkt 1 może nastręczać trudności. Nie jest bowiem tajemnicą, że (zwłaszcza w stosunkach wiejskich) dane ujawnione w urzędowych rejestrach (księga wieczysta, ewidencja gruntów i budynków) z wielu powodów nie są zgodne z rzeczywistością. Przykładem mogą być nieruchomości o nieustalonym stanie prawnym, kiedy to odnoszące się do nich wpisy w urzędowych rejestrach są nieaktualne, chociażby dlatego że ujawniony $\mathrm{w}$ nich właściciel nie żyje. Nie do rzadkości należą też wpisy w ewidencji gruntów i budynków określające władającego jako „NN”, czyli osobę nieznaną. Ustalenie informacji przewidzianych we wspomnianym pkt 1 jest obowiązkiem wnioskodawcy.

Ad. 2. Wnioskodawca musi określić, jakie prawa podmiotowe przysługują mu do nieruchomości (gruntowej) bądź przestrzeni, w granicach których ma być wykonywana zamierzona działalność. Do wspomnianych praw należy przede wszystkim zaliczyć prawo własności nieruchomości, użytkowania wieczystego bądź takie prawa rzeczowe ograniczone lub obligacyjne, których treścią jest możliwość korzystania ze wspomnianych nieruchomości w celu określonym koncesją. W odniesieniu do wnętrza skorupy ziemskiej, w poza granicach przestrzennymi nieruchomości, prawem tym może być wyłącznie użytkowanie górnicze. Określenie „prawa do nieruchomości (przestrzeni)” oznacza konieczność wskazania praw podmiotowych przysługujących wnioskodawcy, bądź to do nieruchomości gruntowej, bądź to do przedmiotu własności górniczej. Ich wspólną cechą musi być to, że muszą one przewidywać możliwość korzystania z danej nieruchomości (bądź przedmiotu własności górniczej) w zakresie niezbędnym do wykonywania wnioskowanej działalności. Szczegóły zależą od tego, czy dana działalność wymaga wyłącznie korzystania z danej nieruchomości (bądź przedmiotu własności górniczej), czy również pobierania jej pożytków. Prawem do nieruchomości gruntowej obejmującym możliwość pobierania jej pożytków przede wszystkim może być prawo jej własności bądź użytkowania wieczystego. Może nim być również użytkowanie w rozumieniu art. 252 i nast. k.c. Wśród praw obligacyjnych należy przede wszystkim wskazać na dzierżawę. Takim prawem przysługującym do przedmiotu własności górniczej może być wyłącznie użytkowanie górnicze. Nie da się również wykluczyć sytuacji polegającej na tym, że wnioskodawca nie legitymuje się żadnym prawem do nieruchomości (przestrzeni objętej własnością górniczą). Musi on wówczas wskazać, o jakie 
prawo podmiotowe (np. użytkowanie górnicze) zamierza się ubiegać ${ }^{6}$. W odniesieniu do nieruchomości gruntowych oznacza to, że wnioskodawca musi zbadać, komu i jakie prawa rzeczowe do nich przysługują, ewentualnie komu. Co prawda posiadanie nie jest prawem podmiotowym, niemniej jednak może mieć znaczenie z punktu widzenia tematu. Wspomniany stan prawny zasadniczo należy ustalić na podstawie treści księgi wieczystej. Znajdujące się w niej wpisy korzystają z domniemania zgodności z prawem. O ile jednak taka księga nie zawiera aktualnych informacji o wspomnianych prawach, „stan prawny nieruchomości” ustala się na podstawie danych znajdujących się w prowadzonej przez starostów ewidencji gruntów i budynków. Wpisy w tej ostatniej nie korzystają jednak z domniemania zgodności z prawem i są wyłącznie dowodem posiadania. Odrębne wymagania dotyczą wniosku o koncesję na wydobywanie kopaliny metodą odkrywkową (art. 26 ust. 1 pkt 2 pr.g.g.). W odniesieniu do górnictwa podziemnego oraz otworowego obowiązek przedstawienia danych dotyczących stanu prawnego nieruchomości dotyczy tylko tych, które mają być wykorzystywane w celu prowadzenia zamierzonej działalności. Wyjątek dotyczy poszukiwania i rozpoznawania węglowodorów. Funkcją rozwiązania przewidzianego w art. 24 ust. 1 pkt 1 pr.g.g. jest ustalenie stron postępowania. Wyłączenie dotyczące węglowodorów nie zwalnia natomiast z konieczności ustalenia tych stron przez organ orzekający w sprawie ani też nie może być interpretowane w ten sposób, że przedsiębiorca może korzystać z takich nieruchomości wbrew woli ich właścicieli (ta ostatnia niekiedy może natomiast zostać zastąpiona orzeczeniem sądu [art. 18 -19 pr.g.g.]).

O ile jednak mają to być prawa pochodne od własności gruntowej, o tyle w interesie wnioskodawcy leży zapewnienie możliwości uzyskania praw o takiej treści, które pozwolą na stabilne prowadzenie zamierzonej działalności. Przykładem może być umowa zobowiązująca do przeniesienia prawa własności bądź ustanowienia innego prawa do nieruchomości zawarta w taki sposób (zwłaszcza w odniesieniu do formy czynności prawnej), aby zapewnić skuteczne uzyskanie zamierzonych praw. Praktyka przeważnie zmierza jednak w odmiennym kierunku, co bywa przyczyną zbędnych komplikacji i opóźnia rozpoczęcie zamierzonej działalności.

Ad. 3. Koncesja w zasadzie jest decyzją terminową, udzielaną na czas od 3 do 50 lat, chyba że wnioskodawca ubiega się o koncesję na czas krótszy niż 3 lata. Wyjątek dotyczy koncesji na podziemne składowanie dwutlenku węgla. Są one udzielane ,na okres uwzględniający obowiązek prowadzenia, po zamknięciu podziemnego składowiska dwutlenku węgla, monitoringu takiego składowiska przez okres nie krótszy, niż 20 lat” (art. 21 ust. 4a). Problem jednak w tym, że w świetle art. 21 pr.g.g. monitoring takiego składowiska nie wyma-

${ }^{6}$ Zob. wyroki WSA z dnia 24 września 2015 r., sygn. akt VI SA/Wa 1917/13 oraz sygn. akt 1938/13. 
ga koncesji. Wskazanie terminu (zamierzonego) rozpoczęcia działalności jest o tyle istotne, że jego niedotrzymanie może powodować nawet cofnięcie koncesji. Nie ma przeszkód, by rozsądnie postępujący wnioskodawca wskazał również przesłanki, których zaistnienie oznacza rozpoczęcie zamierzonej działalności. Bardzo częstym błędem jest natomiast określanie krótkiego terminu rozpoczęcia działalności, w dodatku bez wskazania, jak rozumieć takie „rozpoczęcie”. Warto zwrócić uwagę, że z nielicznymi wyjątkami do działalności stanowiącej przedmiot koncesji stosuje się (odpowiednio lub wprost) wymagania dotyczące ruchu zakładu górniczego, co obejmuje m.in. sporządzenie i zatwierdzenie planu jego ruchu (art. 86, art. 105 i nast. pr.g.g.). Elementami wniosku o zatwierdzenie takiego planu są natomiast „odpisy wymaganych dla zamierzonych robót decyzji wydanych przez inne organy, w szczególności dotyczących ochrony środowiska" (art. 108 ust. 9 pkt 2 pr.g.g.). Ich uzyskanie może wymagać czasu, zwłaszcza że niekiedy przedsiębiorca spotyka się z postawą „bezinteresownej nieżyczliwości" organów właściwych w takich sprawach.

Ad. 4. Ustawa nie określa istoty „środków”, którymi ma dysponować wnioskodawca w celu zapewnienia prawidłowego wykonywania zamierzonej działalności. Powstaje zatem pytanie, czy mają to być środki finansowe czy techniczne (np. maszyny, urządzenia). W warunkach gospodarki rynkowej obowiązek wykazywania się środkami technicznymi nie jest uzasadniony. Określenie wysokości środków finansowych pozostających w dyspozycji wnioskodawcy może natomiast być niezmiernie trudne, przede wszystkim dlatego że żaden przepis ustawy nie wymaga wskazania ich wysokości. Nie jest też tajemnicą, że relacje ekonomiczne (np. wpływające na koszty poszukiwania bądź rozpoznawania złoża kopaliny) mogą ulegać zmianom z przyczyn całkowicie niezależnych od wnioskodawcy. Szczegóły zależą również od rodzaju zamierzonej działalności. Wykonywanie badań geologicznych pociąga za sobą koszty i (w okresie obowiązywania koncesji) nie generuje znaczących dochodów. $Z$ kolei działalność objęta koncesją na wydobywanie kopaliny ze złoża przeważnie musi być poprzedzona robotami udostępniającymi i przygotowawczymi, które w zasadzie również nie są źródłem dochodu. W sumie niesłychanie trudno jest więc odpowiedzieć, jaka ma być wysokość środków określonych komentowanym przepisem. Nie ma przeszkód, by rozsądnie postępujący wnioskodawca, określając wspomniane „środki”, uzasadnił ich wysokość, przedstawiając kalkulację przewidywanych kosztów.

Istota komentowanej regulacji polega na tym, że wspomniane „środki” określa wnioskodawca, wskazując dowody ich istnienia. Nie ma natomiast podstawy prawnej do żądania od wnioskodawcy określonych przez organ koncesyjny dokumentów będących dowodem posiadania wspomnianych „środków” (np. w postaci opinii bankowej, umowy kredytowej, umowy o współpracy połączonej z deklaracją innego podmiotu o finansowaniu przedsięwzięcia). Dostatecznym uzasadnieniem takiego zakazu są art. 7 Konstytucji oraz art. 6 k.p.a. Istota 
problemu polega bowiem na tym, że wnioskodawca ma wykazać, że dysponuje środkami pozwalającymi na wykonywanie zamierzonej działalności, co jednak podlega kontroli organu koncesyjnego. Jeżeli ten ostatni oceni wspomniane środki jako niewystarczające bądź dowody ich istnienia jako niewiarygodne, winien dać temu wyraz w zawiadomieniu, o którym mowa w art. 79a k.p.a. Przewidziano tam, że w postępowaniu wszczętym na żądanie strony organ administracji, informując o możliwości wypowiedzenia się co do zebranych dowodów i materiałów oraz zgłoszonych żądań, ma obowiązek wskazania przesłanek zależnych od strony (wnioskodawcy), które na dzień wysłania tej informacji nie są spełnione lub wykazane, czego konsekwencją może być wydanie decyzji niezgodnej z żądaniem wnioskodawcy. Zdaniem NSA wnioskodawca musi dysponować wspomnianymi środkami w dniu złożenia wniosku koncesyjnego. Niewystarczające są więc deklaracje zapewnienia takich środków, promesy kredytowe itp. (wyrok NSA z dnia 16 czerwca 2016 r., sygn. akt II GSK 73/15). Literalnie rzecz biorąc, ocena ta odpowiada prawu, tyle że koliduje z zasadami racjonalnego gospodarowania. Może ona bowiem oznaczać, że wnioskodawca musi zamrozić posiadane środki co najmniej na czas postępowania koncesyjnego, które może niekiedy trwać nawet kilka lat.

Ad. 5. Nakaz przedstawienia informacji o „obszarach objętych formami ochrony przyrody ${ }^{7}$ bezspornie dotyczy sytuacji, w której zamierzona działalność miałaby być prowadzona w ich granicach. Dotyczy to parków narodowych, rezerwatów przyrody, parków krajobrazowych, obszarów chronionego krajobrazu oraz obszarów Natura 2000 (zwyczajowo zaliczanych do „ochrony obszarowej"). Powstaje natomiast pytanie, czy obejmuje on również te formy, które określane są jako ochrona „obiektowa” bądź ,indywidualna” (pomniki przyrody, stanowiska dokumentacyjne, użytki ekologiczne, zespoły przyrodniczo-krajobrazowe). Bezspornie jednak obiekty objęte tą ostatnią formą ochrony zawsze zajmują określoną „powierzchnię” (obszar), co prowadzi do wniosku, że wspomniany wykaz musi obejmować wszystkie wymienione wyżej formy ochronne $^{8}$. Nie dotyczy to natomiast ochrony gatunkowej. Omawiany obowiązek w istocie sprowadza się do przedstawienia przez wnioskodawcę informacji o obowiązującym stanie prawnym. Wszystkie przywołane formy ochrony przyrody (obszarowe, obiektowe) tworzone są bowiem w drodze przepisów prawa9 Informacja o istnieniu wspomnianych form ochrony jest o tyle istotna, że konsekwencją ich utworzenia są (pośrednio lub bezpośrednio) ograniczenia bądź zakazy wykonywania działalności regulowanej Prawem geologicznym i górni-

$7 \mathrm{~W}$ rozumieniu ustawy z dnia 16 kwietnia 2004 r. o ochronie przyrody (Dz.U. 2020, poz. 55 ze zm.).

8 Zob. D. Danecka, J.S. Kierzkowska, D. Trzcińska, Ograniczenia działalności gospodarczej ze względu na ochrone przyrody, Wolters Kluwer, Warszawa 2018.

$9 \mathrm{~W}$ aktualnie obowiązującym stanie prawnym - przeważnie są to akty prawa miejscowego. Szczegóły zależą jednak od tego, o jaką formę ochrony chodzi i kiedy ją utworzono. 
czym. Opisane wymagania nie dotyczą wniosków koncesyjnych dotyczących przedsięwzięć zaliczonych do kategorii mogących (zawsze bądź potencjalnie) znacząco oddziaływać na środowisko. Otwarty pozostaje natomiast problem, co jeżeli zamierzona działalność miałaby być wykonywana pod powierzchnią nieruchomości, na których zlokalizowano wspomniane formy ochronne. Przykładem może być wydobywanie kopaliny metodą podziemną bądź otworową, ze złoża udostępnionego $\mathrm{z}$ nieruchomości nie objętej wspomnianymi formami ochronnymi.

Ad. 6. Działalność stanowiąca przedmiot koncesji regulowanych komentowaną ustawą nie jest obojętna dla środowiska. Szczegóły zależą od metody jej wykonywania, rozmiarów, stanu środowiska oraz innych czynników. Do największych przeobrażeń środowiska dochodzi w konsekwencji wydobywania kopalin. Wpływy te, ze znacznym prawdopodobieństwem, można prognozować nie tylko w ramach oceny oddziaływania przedsięwzięcia na środowisko. Ten, kto podejmuje działalność mogącą negatywnie oddziaływać na środowisko, ma obowiązek zapobiegania temu oddziaływaniu (tzw. zasada prewencji, art. 6 ust. 1 pr.o.s. $\left.{ }^{10}\right)$. W odniesieniu do wydobywania kopalin powtarza ją art. 126 ust. 1 pr.o.ś. Jeżeli takie oddziaływanie nie jest jeszcze w pełni rozpoznane, podejmujący daną działalność ma obowiązek, kierując się przezornością, podjąć wszelkie możliwe środki zapobiegawcze (tzw. zasada przezorności, art. 6 ust. 2 pr.o.ś). W zakresie, jakim obowiązki te nie zostały określone w decyzji środowiskowej, podlegają weryfikacji dokonywanej w toku postępowania koncesyjnego (zob. art. 30 ust. 2 pr.g.g.).

Ad. 7. Firmą w rozumieniu kodeksu cywilnego jest oznaczenie przedsiębiorcy; musi ona dostatecznie odróżniać się od firm innych przedsiębiorców prowadzących działalność na tym samym rynku. W szczególności nie może ona wprowadzać w błąd co do osoby przedsiębiorcy, przedmiotu oraz miejsca jego działalności. Dalsze szczegóły zależą od prawnego charakteru przedsiębiorcy. Dla osoby fizycznej firmą jest jej imię i nazwisko, z możliwością dołączenia pseudonimu lub określeń wskazujących na przedmiot działalności przedsiębiorcy, miejsca jej prowadzenia oraz innych określeń dowolnie obranych. Dla osoby prawnej firmą jest jej nazwa wraz ze wskazaniem formy prawnej takiej osoby; może ona zostać podana w skrócie oraz może wskazywać przedmiot działalności, siedzibę tej osoby oraz inne określenia dowolnie obrane określenia. Niekiedy firma osoby prawnej może zawierać nazwisko lub pseudonim osoby fizycznej związane z powstaniem bądź działalnością przedsiębiorcy. Dopuszczalne jest posługiwanie się skrótem firmy. Podlega ona ujawnieniu w rejestrze (art. $43^{2-5}$ k.c.).

${ }^{10}$ Ustawa z dnia 27 kwietnia 2001 r. — Prawo ochrony środowiska (Dz.U. 2020, poz. 1219 ze zm., dalej: pr.o.ś.). 
Analiza powyższych rozwiązań uzasadnia ocenę, że z wnioskiem o koncesję na działalność regulowaną prawem geologicznym i górniczym może wystąpić tylko ten, kto już jest przedsiębiorcą z mocy odrębnych przepisów ${ }^{11}$, chyba że ustawa stanowi inaczej. Wypada bronić poglądu, że chodzi tu o „przedsiębiorcę” w rozumieniu Prawa przedsiębiorców, wedle którego jest nim osoba fizyczna, osoba prawna i jednostka organizacyjna niebędąca osobą prawną, której odrębna ustawa przyznaje zdolność prawną, wykonująca we własnym imieniu działalność gospodarczą. Za przedsiębiorców uznaje się także wspólników spółki cywilnej w zakresie wykonywanej przez nich działalności gospodarczej (art. 4). Inaczej mówiąc tzw. zdolność koncesyjną (tj. zdolność prawną do uzyskania koncesji na działalność regulowaną prawem geologicznym i górniczym) mają ci, którzy są przedsiębiorcami w rozumieniu wymagań dotyczących działalności gospodarczej. Formuła ta nie jest jednak ścisła, bowiem z mocy odrębnych wymagań niektórzy przedsiębiorcy podlegają ograniczeniom w zakresie podejmowania niektórych rodzajów działalności gospodarczej. Przykładem mogą być niektóre spółki komunalne. Stosownie bowiem do art. 9 ustawy z dnia 8 marca 1990 r. o samorządzie gminnym ${ }^{12}$ gmina oraz inna gminna osoba prawna może prowadzić działalność gospodarczą wykraczającą poza zadania o charakterze użyteczności publicznej wyłącznie w przypadkach określonych w odrębnej ustawie. Zadaniami użyteczności publicznej, w rozumieniu ustawy, są zadania własne gminy, określone w art. 7 ust. 1, których celem jest bieżące i nieprzerwane zaspokajanie zbiorowych potrzeb ludności w drodze świadczenia usług powszechnie dostępnych. Co prawda formułę te trudno uważać za dostatecznie jasną, tyle że poza sporem jest, że działalność regulowana Prawem geologicznym i górniczym nie mieści się w tak rozumianych, ,zadaniach użyteczności publicznej".

Ad. 8. Wnioskodawca musi wykazać, że jest przedsiębiorcą w znaczeniu wynikającym z art. 4 u.p.p. Prawo geologiczne i górnicze nie wymaga natomiast przedłożenia dowodu wpisu do rejestru przedsiębiorców Krajowego Rejestru Sądowego $^{13}$ (KRS) bądź do Centralnej Ewidencji i Informacji o Działalności Gospodarczej (CEIDG). Wskazanie numeru wpisu do KRS nie oznacza obowiązku przedłożenia wyciągu ze wspomnianego rejestru. Z nieznanych powodów Prawo geologiczne i górnicze pomija obowiązek wskazania numeru wpisu do CEIDG.

Przedmiotem wpisu do CEIDG są przedsiębiorcy będący osobami fizycznymi (art. 17 i n. u.p.p.). Zarówno wpisy w KRS, jak i CEIDG korzystają z tzw.

11 Odmiennie G. Klimek, zdaniem którego o koncesję może ubiegać się każdy podmiot prawa - zob. w: Prawo geologiczne i górnicze. Komentarz Lex, red. B. Rakoczy, Wydawnictwo C.H.Beck, Warszawa 2015, s. 136.

12 Dz.U. 2020, poz. 713 ze zm.

13 Ustawa z dnia z dnia 20 sierpnia 1997 r. o Krajowym Rejestrze Sądowym (Dz.U. 2021, poz. 112, dalej: u.KRS). 
jawności formalnej, czyli są powszechnie dostępne, bez potrzeby wykazywania interesu prawnego w tym zakresie (www.ems.ms.gov.pl; www.prod.ceidg.gov.pl). Pobrane samodzielnie wydruki komputerowe aktualnych informacji o podmiotach wpisanych do KRS, które posiadają cechy umożliwiające ich weryfikację $\mathrm{z}$ danymi zawartymi $\mathrm{w}$ tym rejestrze, mają moc zrównaną z odpisami, wyciągami i zaświadczeniami wydawanymi przez Centralną Informację KRS (art. 4 ust. 4aa u.KRS). Organy administracji publicznej nie mogą domagać się od przedsiębiorców okazywania, przekazywania lub załączania do wniosków zaświadczeń o wpisie w CEIDG (art. 46 ust. 6 ustawy z dnia 6 marca 2018 r. o Centralnej Ewidencji i Informacji o Działalności Gospodarczej i Punkcie Informacji dla Przedsiębiorcy $\left.{ }^{14}\right)$. Dotyczy to również postępowania koncesyjnego.

W praktyce wnioskodawcami najczęściej będą spółki kapitałowe (z ograniczoną odpowiedzialnością, akcyjne) oraz osoby fizyczne. Nie ma natomiast znaczenia, czy tak rozumiany „przedsiębiorca” jest osobą fizyczną bądź osobą prawną (ewentualnie jednostką organizacyjną pozbawioną osobowości prawnej), a zwłaszcza jakie są jego powiązania kapitałowe. Wyjątkiem są koncesje węglowodorowe. Może je uzyskać tylko ten, kto uzyskał status „podmiotu kwalifikowanego"15 (art. 49a i nast. pr.g.g.). Zdolność koncesyjna nie przysługuje tym osobom prawnym, które utworzone zostały $\mathrm{w}$ drodze ustanowienia przepisu prawa (najczęściej w drodze ustawy; przykładem może być Narodowy Fundusz Ochrony Środowiska i Gospodarki Wodnej.

Ad. 9. Określenie „rodzaj” działalności rzecz jasna odnosi się wyłącznie do takiej działalności, która podlega koncesjonowaniu (art. 21 pr.g.g.). Mniej komunikatywne jest wskazanie „zakresu”, zwłaszcza że dalsze wymagania wniosków koncesyjnych ulegają zróżnicowaniu w zależności od rodzaju zamierzonej działalności (art. 25 i nast. pr.g.g.) i obejmują m.in. wielkość przestrzeni, w granicach której ma być prowadzona zamierzona działalność, rozmiary działalności (np. wielkość zamierzonego wydobycia).

Wymagania określone przez art. 24 oraz dalsze przepisy komentowanej ustawy mają charakter obowiązkowy. Nie ma natomiast przeszkód, by wnioskodawca przedstawił we wniosku koncesyjnym również inne dane (okoliczności) uzasadniające jego żądanie. Tak też zresztą bywa w odniesieniu do przedsięwzięć obejmujących działalność o strategicznym znaczeniu dla gospodarki kraju.

Do wniosku należy dołączyć dowody istnienia określonych w nim okoliczności. Najmniej wątpliwości budzi nakaz przedłożenia wypisu z ewidencji gruntów i budynków. W praktyce pojawił się problem wykazywania:

${ }^{14}$ Dz.U. 2020, poz. 2296.

${ }^{15}$ Zob. A. Lipiński, Postępowanie kwalifikacyjne w prawie geologicznym i górniczym, w: XXIV Konferencja „Aktualia i perspektywy gospodarki surowcami mineralnymi”, red. E. Rydzewska, Wydawnictwo Instytutu Gospodarki Surowcami Mineralnymi i Energią PAN, Kraków 2014, s. 161. 
- praw do nieruchomości (określenia praw, o które zamierza ubiegać się wnioskodawca),

- środków, jakimi dysponuje wnioskodawca w celu zapewnienia prawidłowego wykonywania zamierzonej działalności.

Komentowana ustawa nie określa, o jakie dowody tu chodzi. W świetle 75 k.p.a. jako dowód należy dopuścić wszystko, co może przyczynić się do wyjaśnienia sprawy, a nie jest sprzeczne z prawem. W szczególności dowodami mogą być dokumenty, zeznania świadków, opinie biegłych i oględziny (§ 1). Jeżeli przepis prawa nie wymaga urzędowego potwierdzenia określonych faktów lub stanu prawnego w drodze zaświadczenia właściwego organu administracji, ten ostatni, działając na wniosek strony, odbiera od niej oświadczenie złożone pod rygorem odpowiedzialności za fałszywe zeznania, o czym należy uprzedzić zamierzającego złożyć takie oświadczenie (§ 2). Nie ma wątpliwości, że nie istnieje przepis nakazujący wykazanie okoliczności wymienionych w ust. 1 pkt 2 oraz 4 w drodze jakiegokolwiek dokumentu urzędowego. O sposobie wykazania wspomnianych okoliczności przesądza wnioskodawca. Rzecz jasna, przedłożony przez niego dowód może być oceniony jako mało wiarygodny bądź niewystarczający. W takiej sytuacji obowiązkiem organu koncesyjnego jest poinformowanie wnioskodawcy o tym, że nie wykazał on określonej przesłanki niezbędnej do uzyskania koncesji, co może skutkować decyzją odmowną (art. 79 k.p.a.). Organowi koncesyjnemu nie wolno natomiast żądać np. wykazania prawa, o jakie zamierza ubiegać się wnioskodawca, w drodze przedłożenia oferty zawarcia stosownej umowy, przesłanej listem poleconym na adres właściciela nieruchomości. Niedopuszczalne (aczkolwiek znane praktyce) są także żądania przedkładania zaświadczeń o niezaleganiu z podatkami, składkami na ubezpieczenie społeczne, umów kredytowych, opinii bankowych itp. Prawo przedsiębiorców wyraźnie przewiduje, że organ administracji nie może żądać dokumentów lub ujawnienia danych, których konieczność przedstawienia, złożenia lub ujawnienia nie wynika z przepisu prawa lub danych, do których organ ten ma dostęp z mocy innych przepisów (art. 31 zd. drugie). Rozwiązanie (nie zawsze dostrzegane w praktyce niektórych organów koncesyjnych) jest rozwinięciem zasady praworządności (art. 7 Konstytucji, art. 6 k.p.a.).

Źródłem wątpliwości jest nakaz sporządzenia załączników graficznych „,zgodnie z wymaganiami dotyczącymi map górniczych, z zaznaczeniem granic podziału terytorialnego kraju" (art. 24 ust. 3). Przede wszystkim komentowany przepis nie przewiduje przedkładania jakichkolwiek załączników graficznych (map, szkiców). Znany jest on natomiast dalszym przepisom Prawa geologicznego i górniczego, określającym dodatkowe wymagania wniosków koncesyjnych, odrębne dla poszczególnych rodzajów działalności (np. w odniesieniu do map projektowanych obszarów górniczych). W istocie zatem wspomniany ust. 3 określa sposób wykonania obowiązków przewidzianych kolejnymi artykułami komentowanej ustawy. Trudno natomiast ustalić, jak rozumieć ,wymagania do- 
tyczące map górniczych”. Nie określa ich Prawo geologiczne i górnicze. Nie zawiera ono również podstawy do wydania przepisów wykonawczych określających wspomniane wymagania. Te ostatnie są natomiast kształtowane Polskimi Normami $^{16}$, tyle że stosowanie ich jest dobrowolne; mogą natomiast być powoływane w przepisach prawnych (art. 5 ust. 3-4 ustawy z dnia 12 września 2002 r. o normalizacji ${ }^{17}$ ). Polskie Normy nie są publikowane w jakichkolwiek dziennikach urzędowych, dostęp do nich nie jest łatwy i następuje za wynagrodzeniem $^{18}$. Zdaniem NSA „Polska Norma jest normą krajową, przyjętą w drodze konsensu i na podstawie art. 5 ust. 3 ustawy z 2002 r. o normalizacji, stosowanie jej jest dobrowolne. Polskie Normy same w sobie nie są źródłami prawa powszechnie obowiązującego. Powoływanie się na te normy jest zasadne tylko wówczas, gdy przepis ustawy bądź rozporządzenia bezpośrednio odwołuje się do wymogu ich stosowania" (wyrok NSA z dnia 10 kwietnia 2019 r., sygn. akt II OSK 1486/17) ${ }^{19}$. Problem jednak w tym, że Prawo geologiczne i górnicze nie wprowadza nakazu stosowania Polskich Norm. De lege lata taki obowiązek przewiduje rozporządzenie Ministra Środowiska z dnia 28 października 2015 r. w sprawie dokumentacji mierniczo-geologicznej ${ }^{20}$ (§ 4 ust. 3 pkt 2), a zatem sporządzanej na potrzeby zakładu górniczego i jego ruchu ${ }^{21}$. Podobne wymagania dotyczą też szczegółowych wymagań prowadzenia ruchu zakładów górniczych oraz ratownictwa górniczego. Co prawda zdaniem komentatorów Prawa geologicznego i górniczego wymagania wspomnianego rozporządzenia

16 Są to zwłaszcza: PN-G-09000-1:2002 — wersja polska Mapy górnicze — Część 1: Podział i terminologia; PN-G-09000-3:2002 — wersja polska Mapy górnicze — Część 3: Wymagania podstawowe; PN-G-09001:2003:2003/Az1:2007 — wersja polska Mapy górnicze — Definicje, wzorce i symbole barw; PN-G-09003:2003 — wersja polska Mapy górnicze — Umowne znaki obiektów i urządzeń na powierzchni; PN-G-09004:2005 — wersja polska Mapy górnicze - Umowne znaki podziemnych wyrobisk górniczych; PN-G-09005:2004 — wersja polska Mapy górnicze — Umowne znaki surowców mineralnych; PN-G-09006:2005 — Mapy górnicze - Umowne znaki zagrożeń i urządzeń zabezpieczających w wyrobiskach podziemnych; PN-G-09007:2004 — wersja polska Mapy górnicze — Umowne znaki granic; PN-G-09010 wersja polska Mapy górnicze — Umowne znaki geologiczne różne.

17 Dz.U. 2015, poz. 1483 ze zm.

18 Brak podstaw, by zakładać, że ustawa o normalizacji wyłącza stosowanie ustawy o dostępie do informacji publicznej (wyrok NSA z dnia 2 lipca 2003 r., sygn. akt II SA 837/03).

19 Jeżeli co do zasady stosowanie Polskich Norm jest dobrowolne, to nie można skutecznie postawić zarzutu, że organy administracji z nich nie skorzystały przy wyliczaniu powierzchni obiektu budowlanego. Nadanie im waloru przepisów prawa wymaga regulacji szczególnej (wyrok NSA z dnia 4 września 2014 r., sygn. akt II OSK 538/13). Przyjmuje się również, że odesłanie do standardów wynikających z Polskich Norm może wynikać z aktów prawa miejscowego i to nawet wówczas, jeżeli takiej możliwości nie przewiduje ustawa stanowiąca podstawę do ich wydania (wyrok NSA z dnia 1 października 2019 r., sygn. akt II OSK 2050/18).

20 Dz.U. 2015, poz. 1941.

${ }^{21}$ Co jednak nie dotyczy map sporządzanych na potrzeby postępowania koncesyjnego. Odmiennie G. Klimek w: Prawo geologiczne i górnicze. Komentarz Lex..., s. 139. 
znajdują również zastosowanie do map sporządzanych na etapie wniosku koncesyjnego $^{22}$, tyle że nie ma ku temu żadnych podstaw prawnych. Oczywiście nie ma przeszkód, by wnioskodawca dobrowolnie stosował wspomniane wymagania, jednak przedstawienie załącznika graficznego, który ich nie spełnia, nie oznacza jego wadliwości. Na pytanie, czy komentowany art. 24 ust. 3 może być interpretowany jako nakaz stosowania wspomnianych norm, należy udzielić odpowiedzi negatywnej. Ustawodawca od lat nie wykazuje natomiast zainteresowania rozwiązaniem tego problemu, chociażby przez stworzenie podstawy prawnej do wydania rozporządzenia wykonawczego określającego „wymagania dla map górniczych".

Prawo przedsiębiorców wyraźnie przewiduje, że organ koncesyjny nie może:

— żądać ani uzależniać swojego rozstrzygnięcia od przedłożenia dokumentów w formie oryginału, poświadczonej kopii lub poświadczonego tłumaczenia, chyba że obowiązek taki wynika z przepisów prawa (art. 29);

- odmówić przyjęcia pism i wniosków niekompletnych. Nie wolno żądać dokumentów lub ujawnienia danych, których konieczność przedstawienia, złożenia lub ujawnienia nie wynika z przepisu prawa lub danych, które są w posiadaniu organu lub do których ma dostęp na podstawie odrębnych przepisów (art. 31).

Praktyka nie zawsze dostrzega te zależności. Nie do rzadkości należą jednak sytuacje, w których organ koncesyjny eskaluje żądania dotyczące przedstawienia wskazanych przez siebie dokumentów.

Wniosek (wraz z załącznikami) składa się w jednym egzemplarzu. W „uzasadnionych przypadkach organ koncesyjny może żądać złożenia kopii”. O tym, czy dany przypadek jest „,uzasadniony”, rozstrzyga organ koncesyjny. Przykładem może być postępowanie w przedmiocie opinii bądź uzgodnienia zamierzonej koncesji. Formą wspomnianego ,żądania” jest niezaskarżalne postanowienie organu koncesyjnego (art. 123 w zw. z art. 141 § 1 k.p.a.). Można zakładać, że uzasadnieniem dla omawianego żądania będzie potrzeba przeprowadzenia postępowania wyjaśniającego w drodze współdziałania, o którym mowa w art. $7 b$ k.p.a. ${ }^{23}$.

${ }^{22}$ H. Schwarz, Prawo geologiczne i górnicze. Komentarz, T. 1, Wolters Kluwer, Wrocław 2013, s. 209; G. Klimek, Prawo geologiczne i górnicze. Komentarz Lex..., s. 138.

23 Wedle którego „W toku postępowania organy administracji publicznej współdziałają ze sobą w zakresie niezbędnym do dokładnego wyjaśnienia stanu faktycznego i prawnego sprawy, mając na względzie interes społeczny i słuszny interes obywateli oraz sprawność postępowania, przy pomocy środków adekwatnych do charakteru, okoliczności i stopnia złożoności sprawy". Rozwiązanie to nie ma nic wspólnego z opiniowaniem bądź uzgadnianiem wymaganym przez Prawo geologiczne i górnicze. Jego wynik może przybrać wyłącznie postać opinii innych (niż organ koncesyjny oraz organy współdziałające w rozumieniu art. 106 k.p.a.) organów administracji, mających postać zwykłego pisma. O potrzebie i zakresie współdziałania w rozumieniu art. $7 \mathrm{~b}$ k.p.a. dotyczącego omawianych koncesji, samodzielnie rozstrzyga organ koncesyjny. 
W praktyce żądanie przedłożenia już istniejącej („sporządzonej”), przez co należy rozumieć zatwierdzoną dokumentację geologiczną ${ }^{24}$, jest rzadkością. Pomimo istnienia podstawy prawnej takiego żądania (art. 24 ust. 5 pr.g.g.) należy je ocenić jako praktykę biurokratyczną (arg. z art. 31 zd. drugie p.p.). Najczęściej taka dokumentacja jest zatwierdzana przez ten sam organ administracji geologicznej, który jednocześnie jest organem koncesyjnym. Nawet jeżeli zatwierdził ją inny organ administracji geologicznej, organ koncesyjny może bez trudu uzyskać do niej dostęp (art. 7b k.p.a.).

Organ koncesyjny nie może odmówić przyjęcia wniosku niespełniającego wymagań prawa (niekompletnego, art. 31 zd. 1 u.p.p.). W razie złożenia takiego wniosku należy wezwać wnioskodawcę do jego stosownego uzupełnienia pod rygorem pozostawienia sprawy bez rozpoznania. Termin, w jakim należy dokonać uzupełnienia, winien uwzględniać czas niezbędny do jego wykonania, ważny interes publiczny oraz słuszny interes przedsiębiorcy. Nie może on być krótszy niż 7 dni (art. $64 \S 2$ k.p.a. w zw. z art. 30 u.p.p.). Inaczej mówiąc, określając ten termin, organ koncesyjny musi brać pod uwagę rzeczywistą możliwość uzupełnienia braku, słuszny interes strony oraz ważny interes publiczny. Uzupełnienie braków formalnych podania z uchybieniem terminu nie pozwala organowi administracji publicznej na zastosowanie art. $64 \S 2$ k.p.a., gdyż rygor zawarty $\mathrm{w}$ tym przepisie odnosi się wyłącznie do nieusunięcia braków pisma, a nie do ich usunięcia z uchybieniem terminu. Pozostawienie podania bez rozpoznania jest możliwe wówczas, gdy wnoszący je w ogóle nie uzupełnił wskazanego braku formalnego lub uzupełnił go, ale niezgodnie $\mathrm{z}$ wymaganiami precyzyjnie określonymi w wezwaniu (tak NSA w wyrokach z dnia 11 marca 2011 r., sygn. akt II GSK 337/10; z dnia 22 lutego 2012 r., sygn. akt II GSK 3/11, oraz WSA w wyroku z dnia 26 sierpnia 2009 r., sygn. akt II SAB/Gl 51/08). Jeżeli strona usunęła brak formalny po terminie określonym w art. 64 $\S 2$ k.p.a., lecz przed wysłaniem przez organ administracji publicznej pisma informującego o pozostawieniu wniosku bez rozpoznania, stosowanie powołanego przepisu nie jest dozwolone (wyrok WSA z dnia 21 września 2017 r., sygn. akt III SAB/Wr 21/17). Uchybienie takiemu terminowi powoduje pozostawienie sprawy bez rozpoznania, o czym strony są powiadamiane zwykłym pismem. Nie można wykluczyć przywrócenia wspomnianego terminu (art. 58 $\S 1$ k.p.a.). Ocena, czy wniosek koncesyjny spełnia wymagania prawa, może natomiast być przedmiotem sporu pomiędzy organem koncesyjnym a wnioskodawcą. Nie ma znaczenia, jakie są przyczyny tej sytuacji. Wątpliwość ta musi wówczas zostać rozstrzygnięta w drodze decyzji (np. odmawiającej koncesji), co pozwala stronom postępowania (zwłaszcza wnioskodawcy) na poddanie jej kontroli instancyjnej i sądowoadministracyjnej (wyrok NSA z dnia 17 stycznia

\footnotetext{
${ }^{24}$ Bądź „przyjętą” pod rządem dawnych wymagań.
} 
2001 r., sygn. akt II SAB 240/0025). W razie braku takiej decyzji wnioskodawcy mogą przysługiwać środki przewidziane w art. 36 k.p.a. oraz w art. $3 \S 2$ pkt 8 ustawy z dnia 30 sierpnia 2002 r. - Prawo o postępowaniu przed sądami administracyjnymi ${ }^{26}$. Taka decyzja (odmawiająca koncesji) nie wymaga współdziałania z organami określonymi w art. 23 pr.g.g. Stosownie do tego przepisu współdziałania z innymi określonymi tam organami wymaga „udzielenie” koncesji, a nie jej odmowa. Warto też zwrócić uwagę, że taka odmowa udzielenia koncesji dotyczy wyłącznie istniejącego w dacie jej podjęcia stanu faktycznego. Stosowne uzupełnienie wniosku i złożenie go w postaci wymaganej prawem może bowiem skutkować podjęciem wnioskowanej decyzji. Pomimo że przepis ten ma charakter bezwzględnie obowiązujący, praktyka odnotowuje przypadki nieprawidłowości, przede wszystkim polegając na prowadzeniu postępowania koncesyjnego na podstawie wniosku niespełniającego wszystkich wymagań. W świetle ustalonego orzecznictwa sądów administracyjnych tak prowadzone postępowanie nie może doprowadzić do wszechstronnego wyjaśnienia wszystkich istotnych okoliczności sprawy, a w konsekwencji podjęta w takiej sytuacji decyzja będzie wadliwa. Inaczej mówiąc, oznacza to, że również wniosek niespełniający wymagań wszczyna postępowanie koncesyjne.

Wraz z wnioskiem należy wnieść na rachunek organu wykonawczego gminy właściwego ze względu na siedzibę organu koncesyjnego opłatę skarbową za udzielenie koncesji w kwocie 616 zł (art. 6 ust. 1 pkt 3 ustawy z dnia 16 listopada 2000 r. o opłacie skarbowej ${ }^{27}$ ).

W postępowaniach koncesyjnych wyłączone jest stosowanie art. 32 p.p., nakazującego potwierdzenie złożenia wniosku koncesyjnego (art. 21 ust. 2 pr.g.g.). Zasadność tego rozwiązania budzi wątpliwości. Nie ma bowiem przeszkód, by przedsiębiorca zażądał zaświadczenia o złożeniu wniosku (art. 217 k.p.a.) albo by w razie złożenia wniosku w kancelarii urzędu obsługującego organ koncesyjny wnioskodawca zażądał potwierdzenia jego złożenia na kopii wniosku.

Wytknąć należy błędną (i niestety powielaną od lat, a jednocześnie tolerowaną przez niektóre organy koncesyjne) praktykę składania wielostronicowych wniosków koncesyjnych podpisanych wyłącznie na pierwszej stronie. Elementem wniosku jest „podpis” (vidi art. 63 § 3 k.p.a.), co oznacza znak graficzny zamieszczony „pod pismem”. W przeciwnym razie może nie być wiadomo, czy ostatnia strona takiego „wniosku” rzeczywiście nią jest.

Nie istnieją żadne urzędowe wzory wniosków koncesyjnych. Nie ma natomiast przeszkód, by korzystać z wzorów zamieszczonych na stronach interneto-

${ }^{25}$ Gdzie przyjęto, że „odmiennie oceniane przez organ administracji i wnioskodawcę uprawnienia do dokumentacji geologicznej złoża wykraczają poza konstrukcję przyjętą w art. 64 $\S 2$ k.p.a. Te rozbieżności mogą być tylko przedmiotem oceny i rozstrzygnięcia w pozytywnej lub negatywnej decyzji” pod rygorem skargi na bezczynność.

${ }^{26}$ Dz.U. 2019, poz. 2325 ze zm.

27 Dz.U. 2020, poz. 1546 ze zm. 
wych niektórych organów koncesyjnych. Mają one jednak charakter wyłącznie pomocniczy, ułatwiający złożenie poprawnego wniosku.

Dodatkowe wymagania wniosku koncesyjnego stanowią konsekwencję zmian dokonanych przez art. 15 ustawy z dnia 30 marca 2021 r. o zmianie ustawy o udostępnianiu informacji o środowisku i jego ochronie, udziale społeczeństwa w ochronie środowiska oraz ocenach oddziaływania na środowisko oraz niektórych innych ustaw ${ }^{28}$, obowiązującej od dnia 13 maja 2021 r. Do art. 24 dodała ona ust. 6, wedle którego „Do wniosku o udzielenie koncesji, poprzedzonej decyzją o środowiskowych uwarunkowaniach wydaną $\mathrm{w}$ postępowaniu wymagającym udziału społeczeństwa, dołącza się również załącznik graficzny określający przewidywany teren, na którym będzie realizowane przedsięwzięcie, oraz przewidywany obszar, na który będzie oddziaływać przedsięwzięcie, o ile dołączenie tego załącznika było wymagane przez przepisy obowiązujące w dniu złożenia wniosku o wydanie decyzji o środowiskowych uwarunkowaniach, w szczególności mapę, o której mowa w art. 74 ust. 1 pkt 3a" u.o.o.ś. Wedle tego ostatniego chodzi tu o „mapę, w postaci papierowej oraz elektronicznej, w skali zapewniającej czytelność przedstawionych danych $\mathrm{z}$ zaznaczonym przewidywanym terenem, na którym będzie realizowane przedsięwzięcie, oraz z zaznaczonym przewidywanym obszarem, o którym mowa $\mathrm{w}$ ust. 3a zdanie drugie, wraz $\mathrm{z}$ wyznaczoną odległością, o której mowa w ust. 3a pkt 1 [...]”. Wspomniany ust. 3a pkt 1 przewiduje, że obszarem, na który oddziaływać będzie przedsięwzięcie w wariancie zaproponowanym przez przedsiębiorcę, w zasadzie jest ,przewidywany teren, na którym będzie realizowane przedsięwzięcie, oraz obszar znajdujący się w odległości $100 \mathrm{~m}$ od granic tego terenu". Komentarz do tych rozwiązań oraz ocena ich racjonalności wykraczają poza ramy opracowania.

Zob. również komentarz do art. 28ha, dotyczący nadania wnioskowi koncesyjnemu klauzuli poufności.

\section{Art. 24a. \\ Przedsiębiorca jest obowiązany zglaszać organowi koncesyjnemu wszelkie zmiany danych, zawartych we wniosku o udzielenie koncesji, w terminie 14 dni od dnia ich powstania.}

Nie jest tajemnicą, że ustawowe terminy postępowań koncesyjnych nie zawsze są dotrzymywane, a w praktyce trwające nawet kilka lat postępowania koncesyjne nie należą do rzadkości. Nic zatem dziwnego, że w ich toku okoliczności przedstawione we wniosku koncesyjnym mogą ulegać zmianom, np. w odniesieniu do właścicieli nieruchomości, czy innych okoliczności wymaganych zarówno przez art. 24, jak i dalsze przepisy kształtujące wymagania wniosku koncesyjnego. Przykładem mogą być środki, jakimi dysponuje wnioskodawca

\footnotetext{
${ }^{28}$ Dz.U. 2021, poz. 784.
} 
w celu prowadzenia zamierzonej działalności. Podjęcie decyzji w oparciu o nieaktualny wniosek może natomiast powodować, że będzie ona obarczona kwalifikowaną wadą uzasadniającą wznowienie postępowania (art. 145 k.p.a.) czy też nawet stwierdzenie jej nieważności (art. 156 k.p.a.). Komentowany przepis ma na celu uniknięcie takiej sytuacji. Ustawa nie określa sankcji z tytułu zaniedbania wspomnianego obowiązku. Mogą one natomiast wynikać z art. 145 oraz 156 k.p.a. Wypada jednak bronić poglądu, że wspomniany obowiązek nie dotyczy takich danych, które organ koncesyjny ustala bądź może ustalić z urzędu. Dotyczy to np. treści wpisów w CEIDG bądź w KRS. Usytuowanie komentowanego art. 24a zdaje się prowadzić do wniosku, że dotyczy on wyłącznie postępowania koncesyjnego, a nie zdarzeń zaistniałych już po podjęciu decyzji koncesyjnej. Zob. także art. 35 ust. 9 pr.g.g.

Art. 25. 1. We wniosku o udzielenie koncesji na poszukiwanie lub rozpoznawanie złoża kopaliny oraz na poszukiwanie lub rozpoznawanie kompleksu podziemnego składowania dwutlenku węgla określa się również cel, zakres i rodzaj prac geologicznych, w tym robót geologicznych, oraz zamieszcza się informację o pracach, które mają być wykonywane dla osiągnięcia zamierzonego celu, w tym ich technologiach, a w przypadku wniosku o udzielenie koncesji na poszukiwanie lub rozpoznawanie złoża kopaliny wskazuje się także minimalną kategorię rozpoznania złoża.

2. W przypadku zamierzonego wykonywania robót geologicznych, do wniosku, o którym mowa w ust. 1, dołącza się 2 egzemplarze projektu robót geologicznych.

Komentowany artykuł formułuje tzw. dodatkowe wymagania wniosku dotyczącego koncesji na poszukiwanie lub rozpoznawanie złoża kopaliny, jak również kompleksy podziemnego składowania $\mathrm{CO}_{2}$. Dotyczą one określenia celu, zakresu i rodzaju zamierzonych prac (nie tylko geologicznych) oraz ich technologii. O ile inwestor zamierza wykonywać roboty geologiczne (przez co należy rozumieć ,wykonywanie w ramach prac geologicznych wszelkich czynności poniżej powierzchni terenu, w tym przy użyciu środków strzałowych", a także likwidację wyrobisk po tych czynnościach, art. 6 pkt 11 pr.g.g.), niezbędnym elementem wniosku koncesyjnego jest projekt robót geologicznych. W szczególności ma on określać:

- cel zamierzonych robót oraz sposób jego osiągnięcia,

— rodzaj dokumentacji geologicznej mającej powstać w wyniku robót geologicznych,

- harmonogram robót geologicznych,

- przestrzeń, w granicach której mają być wykonywane roboty geologiczne,

- przedsięwzięcia konieczne ze względu na ochronę środowiska, w tym wód podziemnych, sposób likwidacji wyrobisk, otworów wiertniczych, rekulty- 
wacji gruntów, a także czynności mające na celu zapobieżenie szkodom powstałym wskutek wykonywania zamierzonych robót (art. 79 ust. 2 pr.g.g.).

Dalsze wymagania, jakim ma odpowiadać ten dokument, określa rozporządzenie Ministra Środowiska z dnia 20 grudnia 2011 r. w sprawie szczegółowych wymagań dotyczących projektów robót geologicznych, w tym robót, których wykonywanie nie wymaga uzyskania koncesji ${ }^{29}$. Wspomniany projekt z reguły stanowi wielostronicowe opracowanie, w praktyce niestety najczęściej podpisywane przez wnioskodawcę tylko na stronie tytułowej, co jest błędem (zob. komentarz do art. 24 pr.g.g.). Określenie minimalnej kategorii rozpoznania złoża oznacza wskazanie najniższej kategorii dokumentacji geologicznej, która ma powstać w wyniku zamierzonych czynności.

Zob. również komentarz do art. 28ha, dotyczący nadania wnioskowi koncesyjnemu klauzuli poufności.

\section{Literatura}

Agopszowicz A., Zarys systemu prawnego górnictwa. Przejrzat i uzupełnit Aleksander Lipiński, Uniwersytet Śląski, Katowice 1991.

Danecka D., Kierzkowska J.S., Trzcińska D., Ograniczenia działalności gospodarczej ze względu na ochrone przyrody, Wolters Kluwer, Warszawa 2018.

Goss M., Nadzór i regulacja sektora ropy i gazu, Wolters Kluwer, Warszawa 2016.

Jaśkowak M., Wilbrandt-Gotowicz M., Wrólel A., Komentarz aktualizowany do Kodeksu postępowania administracyjnego, System Informacji Prawnej LEX 2019 (wersja elektroniczna).

Kaczmarski L., Instytucja zajęcia stanowiska przez inny organ przy wydawaniu decyzji administracyjnej przez organ właściwy w sprawie, „Casus” zima 2018, nr 91, s. 27-41.

Lipiński A., Postępowanie kwalifikacyjne w prawie geologicznym i górniczym, w: XXIV Konferencja „Aktualia i perspektywy gospodarki surowcami mineralnymi”, red. E. Rydzewska, Wydawnictwo Instytutu Gospodarki Surowcami Mineralnymi i Energią PAN, Kraków 2014, s. $161-173$.

Lipiński A., Prawne podstawy geologii i górnictwa, Wolters Kluwer, Warszawa 2019.

Lipiński A., Mikosz R., Komentarz do ustawy Prawo geologiczne i górnicze, Wydawnictwo ABC, Warszawa 2003.

Mikosz R., Granice koncesjonowania działalności regulowanej prawem geologicznym i górniczym, „Przegląd Prawa Ochrony Środowiska” 2009, nr 2, s. 39-57.

Mikosz R., Koncesja na wydobywanie kopalin jako prawny instrument ochrony środowiska, „Gospodarka Surowcami Mineralnymi” 2008, T. 24, s. 9-25.

Prawo geologiczne i górnicze. Komentarz Lex, red. B. Rakoczy, Wydawnictwo C.H.Beck, Warszawa 2015.

Prawo przedsiębiorców. Komentarz, red. A. Pietrzak, Wolters Kluwer, Warszawa 2019.

Schwarz H., Prawo geologiczne i górnicze. Komentarz, T. 1, Wolters Kluwer, Wrocław 2013.

Wojtulek P., Kocowski T., Małecki W., Prawo geologiczne i górnicze, C.H.Beck, Warszawa 2020.

29 Dz.U. 2011 nr 286, poz. 1696 ze zm. 
Wybrane problemy prawa geologicznego i górniczego, red. B. Rakoczy, Wolters Kluwer, Warszawa 2016.

Zrównoważony rozwój jako czynnik determinujący prawne podstawy zarządzania geologicznymi zasobami środowiska, red. G. Dobrowolski, Wydawnictwo Uniwersytetu Śląskiego, Katowice 2018, https://www.kpgios.us.edu.pl/attachments/article/231/Dobrowolski_Gospodaro wanie_geologicznymi_zasobami_srodowiska_w_swietle_zasady.pdf (dostęp: 23.10.2020).

\title{
Aleksander Lipiński
}

\section{Comment on art. 24-25 of Geological and Mining Act of 9 June 2011}

\author{
Summary
}

Article 24 defines general requirements of license applications, relating to all kinds of licensed activities. They include, in particular, information about the applicant, the type and manner of performing the intended activity, rights to the area within which the activity is to be performed, as well as identification of the resources at the applicant's disposal to achieve this goal. Additional requirements that must be met by an application for a license for prospecting (exploration) of mineral deposits are set out in Art. 25 of the commented act. This applies in particular to the type of mineral sought (explored), the location of the intended works and their technology, as well as the intended accuracy of the mineral deposit identification. The appendix to such application is the geological operations plan.

Key words: license application, geological operations plan

\section{Александер Липиньски}

\section{Комментарий к ст. 24-25 Закона о геологическом и горном праве от 9 июня 2011 г., Зак. вестник за 2014 г., поз. 1064 с изменениями}

\section{Резюме}

Статья 24 определяет так называемые общие требования к заявкам на лицензию, т. е. относящиеся ко всем видам деятельности, подлежащим лицензированию. Они включают, в частности, данные о заявителе, типе и способе осуществления предполагаемой деятельности, правах на пространство, в границах которой эта деятельность должна осуществляться, а также описание ресурсов, имеющихся в распоряжении заявителя для достижения этой цели. Дополнительные требования, которым должна соответствовать заявка на получение лицензии на поиск (разведку) месторождений полезных ископаемых, указаны в ст. 25 комментируемого закона. Это, в частности, относится к типу полезного ископаемого поиск (разведка) которого ведется, месту предполагаемых работ и способу их выполнения, а также к предполагаемой точности разведки месторождения полезных ископаемых. Приложением к такому заявлению является план геологических работ.

Ключевые слова: заявка на концессию, план геологических работ 
Aleksander Lipiński

\section{Commento agli articoli 24-25 della legge del 9 giugno 2011 - Legge geologica e mineraria}

\section{Sommario}

L'articolo 24 stabilisce i cosiddetti requisiti generali per le richieste di licenza, ossia relativi a tutte le attività soggette a licenza. Si tratta, in particolare, dei dati relativi alla persona del richiedente, al tipo e alle modalità di svolgimento dell'attività prevista, ai diritti negli spazi all'interno dei quali l'attività deve essere svolta e ai mezzi a disposizione del richiedente per realizzarla. L'articolo 25 della legge specifica i requisiti supplementari che devono essere soddisfatti da una domanda di autorizzazione per la ricerca (prospezione) di giacimenti minerari. Ciò riguarda, in particolare, l'indicazione del tipo di minerale oggetto della prospezione (esplorazione), l'ubicazione delle opere previste e le modalità di realizzazione, nonché la precisione prevista per l'esplorazione del giacimento. L'allegato a tale domanda è una bozza di opere geologiche.

Parole chiave: richiesta di licenza, bozza di opere geologiche 